\title{
Sciendo
}

\section{The statistical relation/coherence between ice-regimes of Lake Raduńskie Górne and Lake Ostrzyckie}

\author{
Jacek Barańczuk \\ Department of Limnology, University of Gdansk, Bażyńskiego 4, 80-309 Gdańsk, Poland, e-mail: bgiojb@univ.gda.pl
}

\begin{abstract}
This article is an attempt to analyse and compare several selected parameters regarding ice phenomena using the correlation analysis of two lakes, which are benchmark lakes located in the central part of the Kashubian Lakeland. These lakes are: Raduńskie Górne, a larger one $\left(387.2 \mathrm{hm}^{2}\right)$ and Ostrzyckie, a smaller one covering an area of $308.0 \mathrm{hm}^{2}$. The analysis covered measurement sequences for the period 1971-2010. The material for analysis regarding data on ice phenomena on Lake Raduńskie Górne was obtained from the University of Gdańsk Limnological Station in Borucino while the data for Lake Ostrzyckie was obtained from the Institute of Meteorology and Water Management (IMGW). Relations between the following parameters of the ice regime were analysed: duration of the ice phenomena, duration of the ice cover, average and maximum thickness of the ice cover. The analysis and data comparisons have revealed that there are strong and very strong relations between the analysed parameters, which made it possible to develop proper statistical models. Hence, should there be a lack of data on the ice-cover pattern for one of these lakes it is possible to recreate them using the elaborated empirical models and data for the other.
\end{abstract}

Key words: lake ice, ice-cover pattern, ice thickness, trend analysis

\section{Introduction}

The climate of the Kashubian Lakeland is mainly shaped by air masses approaching from the North Atlantic Ocean. Development of ice phenomena on lakes depends on variations in air temperature and the durability of its negative values (Miętus 2006). During a winter with relatively high air temperatures ice cover is observed for short periods while its thickness does not exceed several centimetres, or it is not observed at all. On the other hand, when severe frost occurs, a stable, up to $50 \mathrm{~cm}$ thick, ice cover is formed which can last up to 123 days (Barańczuk et al. 2017).

Development of ice phenomena also depends on morphological and hydrological conditions. Because the topography of the Kashubian Lakeland is highly diverse, its local climates are also diversified, although the region does not cover a large area (Barańczuk and Marchlewicz 2003). This climatic diversification is reflected in the different ice regimes observed on two neighbouring lakes with similar morphometric profiles. The topography affects spatial differentiation of air temperature and air flow directions in the ground-level atmospheric air. Raduńskie Górne Lake is a very good example of specific anemometric conditions where winds blowing along the longer axis of the lake trough constitute $73.3 \%$ of all the winds blowing there (Barańczuk and Marchlewicz 2003). That is the primary reason why the ice cover in this lake develops later than in the case of Lake Ostrzyckie.

Thus, a question arises regarding the relation between ice-cover regimes of lakes located relatively close to each other, and whether it is possible to extrapolate ice pattern data from one lake (a hydrometrically controlled lake) to another, temporary lack of such data. Therefore, the main objective of this paper is to assess the strength of the statistical relations existing between selected ice regime parameters of these two lakes, which were monitored over a long-term in the period between 1971 and 2010.

\section{Study objects}

In order to assess the strength of a statistical link between ice regimes of lakes situated close to each other, two lakes located in the Polish Lowlands to the west of the River Vistula were chosen. These lakes are Raduńskie Górne and Ostrzyckie (Fig. 1). They are located in a mesoregion of the Kashubian Lakeland (Kon- 


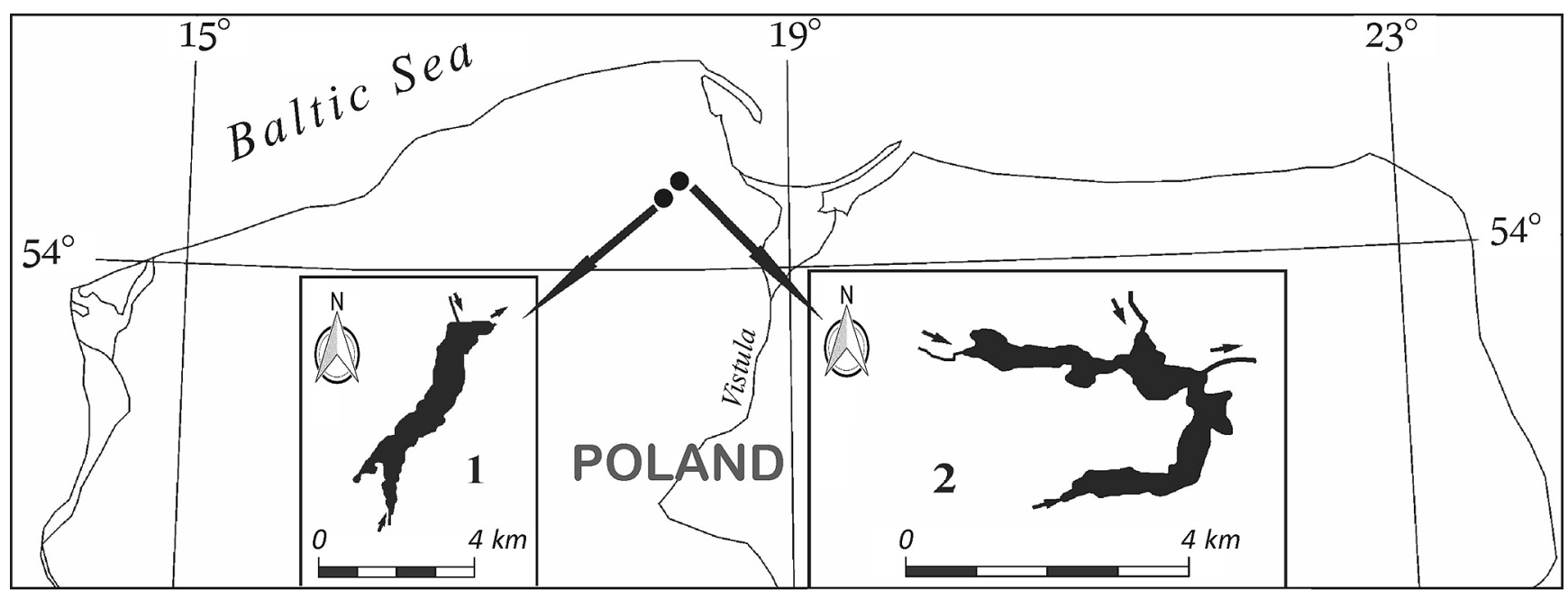

Fig. 1. Location map of the studied lakes

1 - Lake Raduńskie Górne, 2 - Lake Ostrzyckie.

dracki 2011), forming a part of the riverine-lake system of the Upper Radunia River. Both lakes represent differentiated hydrological and geomorphologic conditions.

Morphogenetically, Lake Ostrzyckie is a typical ribbon lake, while Lake Raduńskie Górne is a structuralribbon lake (Jańczak 2002). Elevations of the water surface of these lakes are 159.4 and $161.3 \mathrm{~m}$ a.s.l., respectively. Lake Raduńskie Górne is the second (area: $387.2 \mathrm{hm}^{2}$, volume: $60158.7 \mathrm{dam}^{3}$ ) and Lake Ostrzyckie the third largest (area: $308.0 \mathrm{hm}^{2}$, volume: 20785.2 $\mathrm{dam}^{3}$ ) water body within the Radunia-Ostrzyce subglacial valley (Borowiak and Barańczuk 2006; Borowiak et al. 2011). Both lakes are of a flow-through type. According to hydrological typology of Polish lakes (Pasławski 1975) Lake Raduńskie Górne has a passive, while Lake Ostrzyckie moderate hydrological type. The water residence times were calculated as 2.38 and 0.26 yr, respectively.

\section{Methods}

The analysed data on the ice phenomena on Lake Ostrzyckie in the period 1971-2010 was obtained from the Institute of Meteorology and Water Management (IMGW). The measurements of ice phenomena on this lake were carried out in accordance with the IMGW recommendations near the gauge station every 5 days during the ice season (Świrski 1947).

The material for analysis regarding data on ice phenomena on Lake Raduńskie Górne was obtained from the University of Gdańsk Limnological Station in Borucino. The station is situated in the north-western part of the lake, the so called Borucino Basin. The data covers the period of 1971-2010 and the measurements were carried out each day during the ice season (Barańczuk 2015).
All time measurement data collected for each lake have been converted to mean and extreme values, after which empirical models were calculated for the following parameters of the ice regime: duration of the ice cover, average and maximum thickness of the ice cover. The strength of the statistical relations was assessed with the use of determination and indetermination factors.

\section{Results}

Ice phenomena are defined as presence of ice in water no matter what the ice structure, form and time of its occurrence (Choiński 2007). By and large, the ice regime of Lake Raduńskie Górne is similar to that of Lake Ostrzyckie (Fig. 2). Thus, there is a statistically significant link between the time of ice phenomena occurrence on the two benchmark lakes - Raduńskie Górne $\left(\mathrm{IP}_{\mathrm{RG}}\right)$ and Ostrzyckie (IP $\left.{ }_{\mathrm{OS}}\right)$. On the basis of data covering the analysed period this link can be described by

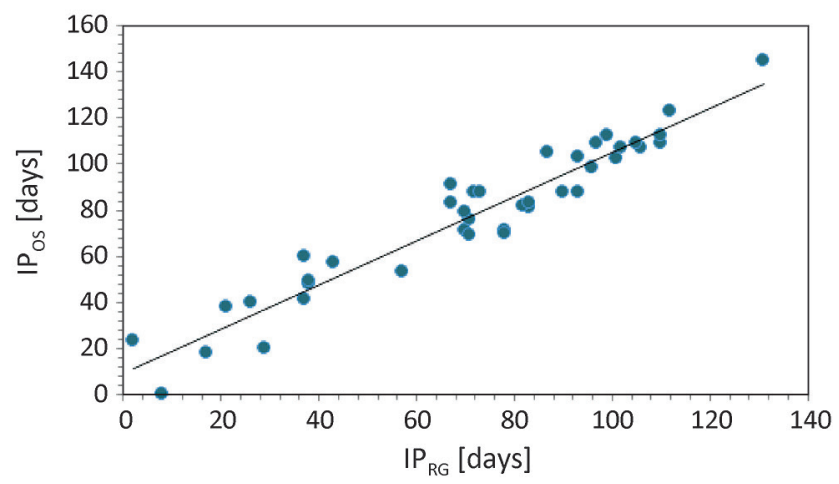

Fig. 2. Relationship between the duration times of the ice phenomena occurrence (IP) in lakes Raduńskie Górne and Ostrzyckie in the period of 1971-2010 


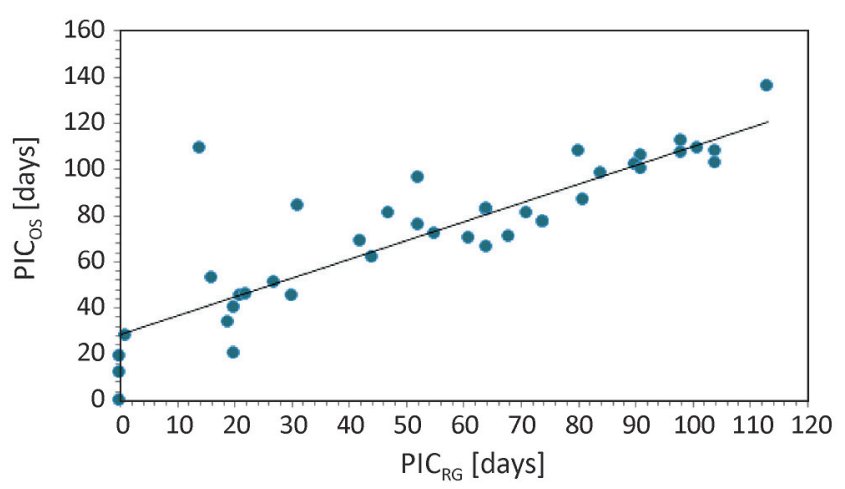

Fig. 3. Relationship between the duration time of the permanent ice cover occurrence (PIC) in lakes Raduńskie Górne and Ostrzyckie in the period of $1971-2010$

the following equation: $\mathrm{IP}_{\mathrm{OS}}=0.960\left(\mathrm{IP}_{\mathrm{RG}}\right)+8.970, \mathrm{R}^{2}$ $=0.921, \mathrm{p}=0.05$, where: $\mathrm{IP}_{\mathrm{RG}}-$ number of days with ice phenomena on Lake Raduńskie Górne, $\mathrm{IP}_{\mathrm{OS}}$ - number of days with ice phenomena on Lake Ostrzyckie.

The statistical analysis has shown that the occurrence of ice phenomena in Lake Ostrzyckie lasts 8-9 days longer than in Lake Raduńskie Górne. However, average values of the ice phenomena duration time observed during the considered period were 80 days in Lake Ostrzyckie and 77 days in Lake Raduńskie Górne (Barańczuk 2015). The longest period with ice phenomena in Lake Ostrzyckie lasted 145 days and it was recorded in 1996; the shortest was recorded in 2008 and lasted only 18 days. In the case of Lake Raduńskie Górne, the longest period, lasting 141 days, was recorded in 1996 and the shortest one, amounting to only two days, in 1990.

In order to assess the relation between the ice regimes of the two analysed lakes more precisely another parameter has been taken into consideration. The analysis has indicated that there is also a significant correlation between the permanent ice cover duration time in Lake Raduńskie Górne ( $\mathrm{PIC}_{\mathrm{RG}}$ ) and Lake Ostrzyckie $\left(\mathrm{PIC}_{\mathrm{OS}}\right)$, yet of lower statistical strength than the one regarding the ice phenomena duration time (Fig. 3). This relationship can be described by the following equation: $\mathrm{PIC}_{\mathrm{OS}}=0.813\left(\mathrm{PIC}_{\mathrm{RG}}\right)+28.62, \mathrm{R}^{2}=0.745, \mathrm{p}$ $=0.05$, where: $\mathrm{PIC}_{\mathrm{RG}}$ - number of days with permanent ice cover in Lake Raduńskie Górne, PIC $_{\mathrm{OS}}$ - number of days with permanent ice cover in Lake Ostrzyckie.

The statistical analysis has shown that the permanent ice cover duration time is fundamentally 3-4 weeks longer in Lake Ostrzyckie than in Lake Raduńskie Górne. The range of permanent ice cover duration time in Lake Raduńskie Górne was between 1 day in 1989, and 113 days in 1996. As for Lake Ostrzyckie it was between 12 and 136 days in 2008 and 1996, respectively. In an average year permanent ice cover occurs for 75 days in Lake Ostrzyckie and only for 65 days in Lake

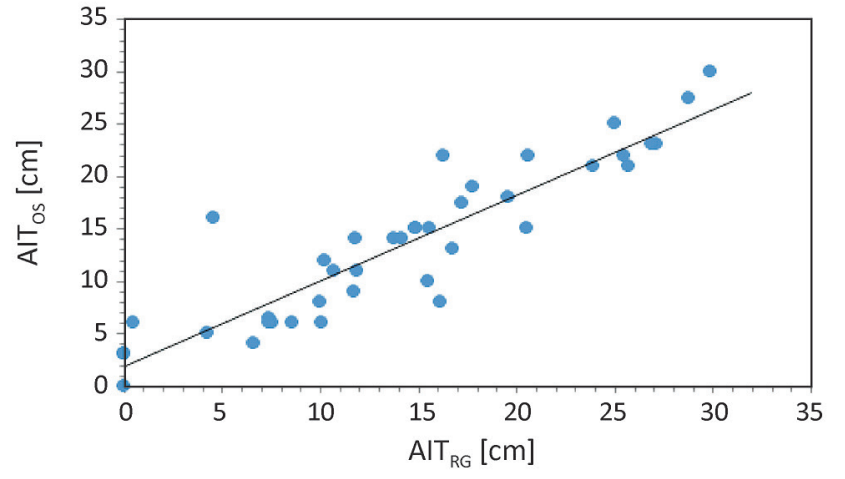

Fig. 4. Relationship between the mean thickness of the ice cover (AIT) during winter season in lakes Raduńskie Górne and Ostrzyckie in the period of 1971-2010

Raduńskie Górne (Barańczuk 2015). Recognition of the duration time of ice phenomena and permanent ice cover occurrence has shown that the ice regime of Lake Ostrzyckie turns out to be more stable over time.

The ice cover thickness parameters in both lakes are also statistically linked. The relation between the mean thickness of the ice cover in the whole ice season can be expressed by the following linear equation: $\mathrm{AIT}_{\mathrm{OS}}=0.819\left(\mathrm{AIT}_{\mathrm{RG}}\right)+1.882, \mathrm{R}^{2}=0.825, \mathrm{p}=0.05($ Fig. 4), where: $\mathrm{AIT}_{\mathrm{RG}}$ - mean thickness of the ice cover in Lake Raduńskie Górne, AIT $_{\text {os }}$ - mean thickness of the ice cover in Lake Ostrzyckie. In turn, the relationship between the maximum thicknesses of the ice cover between the lakes describes the following equation: $\mathrm{MIT}_{\mathrm{OS}}=0.807\left(\mathrm{MIT}_{\mathrm{RG}}\right)+6.168, \mathrm{R}^{2}=0.801, \mathrm{p}=0.05$, where: $\mathrm{MIT}_{\mathrm{RG}}$ - maximum thickness of the ice cover in Lake Raduńskie Górne, MIT $_{\mathrm{OS}}$ - maximum thickness of the ice cover in Lake Ostrzyckie.

Long-term observations have shown that the mean ice cover thickness in Lake Ostrzyckie varied from 3 to $30 \mathrm{~cm}$ (Fig. 4), most frequently reaching $6 \mathrm{~cm}$. In the case of the second studied lake, its mean ice cover thickness ranged from 0.5 to $38.5 \mathrm{~cm}$, but the most common

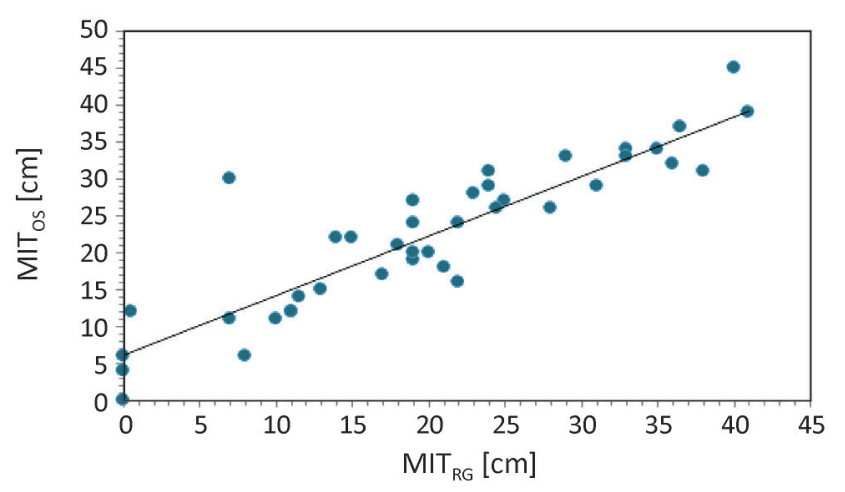

Fig. 5. Relationship between the maximum thickness of the ice cover (MIT) during winter season in lakes Raduńskie Górne and Ostrzyckie in the period of 1971-2010 
value was $11.5 \mathrm{~cm}$. In turn, the maximum thickness of the ice cover in Lake Ostrzyckie ranged from 4 to $45 \mathrm{~cm}$ (Fig. 5), most frequently reaching $12 \mathrm{~cm}$, while in Lake Raduńskie Górne its value oscillated between 0.5 and $41 \mathrm{~cm}$, reaching usually $19 \mathrm{~cm}$.

The ice-monitoring data has also indicated that the average ice cover thickness recorded during all the ice seasons of the period of 1971-2010 was similar in both lakes, and reached $14 \mathrm{~cm}$. However, the maximum thickness during the same period was $2 \mathrm{~cm}$ higher in Lake Ostrzyckie (Barańczuk 2015).

\section{Discussion}

Observations and measurements regarding ice phenomena constitute a complementary part of research on thermal characteristics of lakes. The ice cover isolates, to a significant extent, the lake environment from numerous exogenous factors. In such conditions not only is the energy exchange with the ambient environment limited, but also the intensity of the majority of the phenomena taking place in a particular water body (Lange 1993; Karetnikov and Naumenko 2008).

Ice phenomena are a visible effect of the decreasing temperature of surface water during the winter. Ice cover starts to form when the temperature of the surface water reaches approximately $0^{\circ} \mathrm{C}$ and its thickness dependently isolates the water column from such exogenous factors like air temperature or wind (Bengtsson 1996; Trusewicz et al. 2011). Ice phenomena occurred in Lake Raduńskie Górne every winter (Borowiak and Barańczuk 2004; Barańczuk et al. 2017) while in Lake Ostrzyckie there was only one winter, the winter of 2007, when ice phenomena was not observed at all (Skowron 2011; Barańczuk 2015). In the literature one can find other examples of Polish lakes without ice phenomena in some years (for example lakes: Lubie, Charzykowskie), which were monitored during the same period (Marszelewski and Skowron 2009), as well as these in which ice cover is observed every year (Marszelewski and Skowron 2009; Choiński et al. 2014, Choiński 2016, Choiński 2017).

As for the case of the statistical link between ice phenomena duration times in lakes Ostrzyckie and Raduńskie Górne, the correlation coefficient reaching $0.960(\mathrm{p}<0.5)$ confirms a significant similarity of the ice regimes of these two lakes. An existing relationship has also been confirmed by a very high coefficient of determination (0.921). This means that inter-annual changes of the ice phenomena duration times in Lake Ostrzyckie in more than $92 \%$ can be explained by its changes observed in Lake Raduńskie Górne (same regional factors). Consequently, these changes are driven by local factors in less than $8 \%$, which either do not in- fluence, or influence the ice phenomena duration time in a different way in both lakes. Thus, it can be stated that almost every unity change in the ice phenomena duration time in Lake Ostrzyckie corresponds to a unity change of this parameter observed in the second analysed lake (Fig. 2).

Nonetheless, the relation between the duration times of permanent ice cover occurrence in Ostrzyckie and Raduńskie Górne lakes is not so strong. The correlation coefficient reached 0.864 , which means that the relationship connecting this parameter is less strong than in the case of the first one. The coefficient of determination, reaching only 0.745 , also proved this observation. More than $25 \%$ of the inter-annual changes of the permanent ice cover duration time in Lake Ostrzyckie depend strictly on local factors, which do not affect the duration time of the ice cover in Lake Raduńskie Górne (Kuusisto 1994; Williams et al. 2004; Borowiak and Barańczuk 2004; Barańczuk and Borowiak 2005). The points on the graph showing this relationship are more scattered along the trend line (Fig. 3).

The relationships between the ice cover thickness parameters in the studied lakes also proved to be highly statistically significant (Figs 4 and 5). The correlation coefficients between mean thicknesses, as well as between maximum thicknesses of the ice cover were almost similar and reached 0.909 and 0.895 , respectively, while corresponding to them coefficients of determination amounted to 0.825 and 0.801 . Hence, in the case of ice thickness parameters, the influence of local factors differentiating these components of the ice regimes of studied lakes can be estimated at a level of $17.5-20 \%$. The impact of the large-scale (global) factors that affect regional climate conditions in both cases exceeds $80 \%$. Earlier works have shown that a large ocean-atmospheric anomaly such as the North Atlantic Oscillation (NAO) significantly affects mean ice thickness, as well as duration time of ice phenomena and ice cover in Lake Raduńskie Górne. Inter-annual changes of these ice regime parameters can be explained by the winter NAO index of 53-61\% (Borowiak and Barańczuk 2004).

Despite the global factors recently shortening the duration time of ice periods in lakes of the northern hemisphere (Duguay et al. 2003, Duguay et al. 2006) the above analyses have shown that there are some other local factors affecting the ice regime observed in lakes situated close to each other (Kärkäs 2000). Such factors are, for example: land elevations, nearby forests or changing wind conditions (Ghanbari et al. 2009) related to the diverse topography of the Kashubian Lakeland (Barańczuk et al. 2017). The shifted course of the ice phenomena in the studied lakes may also depend on local factors affecting the heat content accumulated in the lake in the period before the onset of ice formation. The 
more heat that has been accumulated in the lake in this period, the later the ice phenomena occur (Barańczuk 2015). In an average year, in the deeper (mean depth $15.5 \mathrm{~m}$ ) and larger Lake Raduńskie Górne relative heat content is nearly equal to $808 \mathrm{MJ} \mathrm{m}^{-2}$. For comparison in the shallower (mean depth $6.7 \mathrm{~m}$ ) and much smaller Lake Ostrzyckie this value is almost twofold lower and reaches only $480 \mathrm{MJ} \mathrm{m}^{-2}$. Lake Raduńskie Górne also has much better conditions of light transmission within the water column. In this lake the euphotic zone depth exceeds $7.5 \mathrm{~m}$, while in Lake Ostrzyckie it does not even reach $4.5 \mathrm{~m}$ (Borowiak 2011). Thus, the solar radiation can penetrate the water column more deeply in the first lake.

These lakes also differ significantly in terms of flushing rates, which are 0.42 and $3.92 \mathrm{yr}^{-1}$, respectively, in Lake Raduńskie Górne and Lake Ostrzyckie (Borowiak 2011). Therefore, Lake Ostrzyckie is characterised by distinctly lower heat retention (Barańczuk 2015).

\section{Conclusions}

The presented analyses and data comparisons have indicated that the strength of the correlation between selected parameters of the lake ice-regime of two Kashubian lakes was very strong $(\mathrm{r}>0.80)$ or strong $(\mathrm{r}$ $>0.60$ ). It can be stated that the data on ice-regime parameters collected for Lake Raduńskie Górne may be used when assessing the ice-regime of the neighbouring Lake Ostrzyckie. With the use of a prepared set of empirical equations it is possible to predict accurately such variables as: duration time of ice phenomena, duration time of the ice cover as well as the maximum and mean ice cover thickness in such cases as a complete lack of data or unexpected interruptions in the five-day measurement cycle.

\section{Acknowledgements}

I would like to thank my wife Katarzyna Barańczuk for her understanding, patience and invaluable help in preparing the final version of the manuscript.

\section{References}

Barańczuk J., 2015, Przebieg zjawisk lodowych na wybranych jeziorach Pojezierza Kaszubskiego (The course of ice phenomena on the selected lakes of the Kashubian Lakeland) [Phd Thesis], Department of Limnology, University of Gdańsk, Gdańsk, 231 pp (in Polish).

Barańczuk J., Bajkiewicz-Grabowska E., Barańczuk K., Staszek W., 2017, The ice regime of Lake Raduńskie Górne (Kashubian Lakeland, northern Poland), Limnol Rev. 2: 61-70.
Barańczuk J., Borowiak D., 2005, Zjawiska lodowe jezior (Lakes ice cover), [in:] Lange W. (ed.), Jeziora górnej Raduni i jej zlewnia w badaniach $\mathrm{z}$ udziałem Stacji Limnologicznej w Borucinie (Lakes of the upper Radunia River and its catchment in research with the participation of the Limnological Station in Borucino), Ser. Bad. Limnol. 3, Wydaw. KLUG, Gdańsk: 251-260 (in Polish, English summary).

Barańczuk J., Marchlewicz R., 2003, Diversity of development of ice phenomena in chosen lakes of Kaszubskie Lakeland in winter 2003, Limnol. Rev. 3: 25-30.

Bengtsson L., 1996, Mixing in ice-covered lakes, Hydrobiologia 322: 91-97.

Borowiak D., 2011, Właściwości optyczne wód jeziornych Pomorza (Optical properties of the Pomeranian lake waters), Wydaw. UG, Gdańsk, 275 pp (in Polish, English summary).

Borowiak D., Barańczuk J., 2004, Secular fluctuations of ice phenomena in Raduńskie Górne Lake, Kashubian Lakeland, Limnol. Rev. 4: 17-24.

Borowiak D., Barańczuk J., 2006, Diversity of surface outflow from lakes which perform different hydrological functions, Limnol. Rev. 6: 13-20.

Borowiak D., Nowiński K., Barańczuk J., Marszelewski W., Skowron R., Solarczyk A., 2011, Relationship between areal hypolimnetic oxygen depletion rate and the trophic state of five lakes in northern Poland, Limnol. Rev. 4: 135-142.

Choiński A., 2007, Examples of variation in ice cover thickness in mountain and lowland lakes in Poland, Limnol. Rev. 7(1): 11-18.

Choiński A., 2016, Ice phenomena on Lake Czarny Staw pod Rysami, Limnol. Rev. 16(3): 165-169.

Choiński A., 2017, Ice phenomena on Lake Wielki Staw in the Valley of Five Polish Lakes, Limnol. Rev. 17(2): 71-77.

Choiński A., Ptak M., Skowron M., 2014, Tendencje zmian zjawisk lodowych jezior Polski w latach 1951-2010 (Tendencies of changes of the ice phenomena in Polish lakes in the period 1951-2010), Prz. Geogr. 86(1): 23-40 (in Polish, English summary).

Duguay C.R., Flato G.M., Jeffries M.O., Ménard P., Morris K., Rouse W.R., 2003, Ice-cover variability on shallow lakes at high latitudes: model simulations and observations, Hydrol. Process. 17: 3465-3483.

Duguay C.R., Prowse T.D., Bonsal B.R., Brown R.D, Lacroix M.P., Ménard P., 2006, Recent trends in Canadian lake ice cover, Hydrol. Process. 20: 781-801.

Ghanbari R.N., Bravo H.R., Magnuson J.J., Hyzer W.G., Benson B.J., 2009, Coherence between lake ice cover, local climate and teleconnections (Lake Mendota, Wisconsin), J. Hydrol. 374: 282-293.

Jańczak J., 2002, Morphogenetic types of Polish Lowland postglacial lakes and their evolution, Limn. Rev. 2: 181189.

Karetnikov S.G., Naumenko M.A., 2008, Recent trends in Lake Ladoga ice cover, Hydrobiologia 599: 41-48. 
Kärkäs E., 2000, The ice season of Lake Pääjärvi in Southern Finland, Geophysica 36(1-2): 85-94.

Kondracki J., 2011, Geografia regionalna Polski (Regional Geography of Poland), Wyd. PWN, Warszawa, 441 pp (in Polish).

Kuusito E., 1994, The thickness and volume of lake ice in Finland in 1961-90, Publ. of the Water and Environm. Res. Inst. No 17, National Board of Waters and Environment, Helsinki: 27-36.

Lange W. (ed.), 1993, Metody badań fizycznolimnologicznych (Methods of physicolimnological studies), Wydaw. UG, Gdańsk, 175 pp (in Polish).

Marszelewski W., Skowron R., 2009, Extreme ice phenomena on the lakes of Northern Poland, Limnol. Rev. 9(2-3): 81-89.

Miętus M. (red.), 2006, Klimat rynny Jezior Raduńskich (Climate of the channel valley of the Radunia Lakes), Wydaw. IMGW, Warszawa, 211 pp (in Polish).

Pasławski Z., 1975, Typologia hydrologiczna jezior Pojezierza Wielkopolskiego (Hydrological typology of lakes of the Wielkopolskie Lake District), Prz. Geofiz. 20(4): 271-280 (in Polish, English summary).

Skowron R., 2011, Zróżnicowanie i zmienność wybranych elementów reżimu termicznego wody w jeziorach na Niżu Polskim (Diversity and variability of selected elements of the thermal regime of water in lakes in the Polish Lowlands), Wydaw. Nauk. UMK, Toruń, 345 pp (in Polish, English summary).

Świrski Z., 1947, Wskazówki dla obserwatora stacji wodowskazowej (Recomendation for the observer of the water gauging post), Ser. A: Instrukcje i podręczniki $\mathrm{Nr}$ 8, PIHM, Warszawa, 31 pp (in Polish).

Trusewicz Z., Markowski M., Barańczuk J., 2009, The influence of the North Atlantic Oscillation on variability of surface temperature of Lake Raduńskie Górne, Limnol. Rev. 9(2-3): 55-62.

Williams G., Layman K.L., Stefan H.G., 2004, Dependence of lake ice covers on climatic, geographic and bathymetric variables, Cold Regions Sci. Technol. 40: 145-164. 